\title{
Performance of Some Alfalfa Cultivars under Salinity Stress Conditions
}

\author{
A. E. Badran ${ }^{1}$, Esraa A. M. ElSherebeny ${ }^{1} \&$ Y. A. Salama ${ }^{1}$ \\ ${ }^{1}$ Genetic Resources Department, Desert Research Center, Cairo, Egypt \\ Correspondence: A. E. Badran, Genetic Resources Department, Desert Research Center, Cairo, Egypt. E-mail: \\ dr.ayman_badran@yahoo.com
}

Received: July 9, 2015 Accepted: August 13, 2015 Online Published: September 15, 2015

doi:10.5539/jas.v7n10p281 URL: http://dx.doi.org/10.5539/jas.v7n10p281

\begin{abstract}
The experiment was aimed at assessing the response of three alfalfa (Medicajo sativa L.) varieties viz., Giza 1, Al-hasawi and Siwa 1 under two salinity levels during 2012 and 2013 growing seasons. The statistical analysis revealed significant differences among varieties for various traits associated with salt tolerance under salinity stress. Regarding to stress tolerance index, the results confirm that Al-hasawi cv. and Siwa $1 \mathrm{cv}$. were found to be more tolerant of salinity than Giza $1 \mathrm{cv}$. According to correlation and path analysis, proline and chlorophyll content recorded the highest positive direct effect on dry weight per plant (1.135 and 0.693 respectively,). At biochemical level, analysis of soluble protein by SDS-PAGE revealed that percentage of polymorphic and monomorphic were 75 and 25 respectively. Also, the molecular weights of some salt responsive proteins (16.4, $29.5,33.9$ and $37 \mathrm{kDa}$ ) are necessary to select the tolerant varieties under salinity stress in alfalfa plant.
\end{abstract}

Keywords: alfalfa, salinity, path analysis, tolerance index, SDS-PAGE

\section{Introduction}

A biotic stress is the prime cause of decreasing in main agricultural products throughout worldwide (Valliy \& Ngvyen, 2006). On the basis of their tolerance to salt, plant species can be subdivided into four groups, namely (1) salt tolerant, (2) moderately salt tolerant, (3) moderately salt sensitive and (4) salt sensitive (Katerji et al., 2003). Alfalfa is moderately sensitive to salt levels in irrigation water and soil (Mass \& Hoffman, 1977), but its great genetic variability (Julier et al., 2000; Wang et al., 2011) may be useful to select the most salt tolerant genotypes among and within the varieties. The success of appropriate selection techniques depends on the ability to exploit this variability. Salt tolerance is achieved due to the control of salt movement into and through the plant. Salt-specific effects on growth are seen only after long periods of time (Munns et al., 2000). Analysis of alfalfa growth has shown that it responds to an onset of water stress by a reduction in shoot and root elongation (Carter \& Sheafer, 1983a). Also, Brown and Tanner (1983) found the reduced leaf area, inter-node length and proline content is also known to play a vital role in plant drought tolerance and its levels are considerably increased in plants under water deficit stress.

In the field experiments, stress tolerance parameters, based on yield reduction under stress conditions in comparison to non-stress conditions are generally used to identify stress tolerant genotypes (Mitra, 2001). The relative yield performance of genotypes in drought stressed and more appropriate environments seems to be a common beginning point in identification of traits related to drought tolerance and selection of genotypes for use in breeding for dry environments (Clarke et al., 1992). In the same manner, to reveal traits having an influence on a final trait, path analysis is commonly used as reported Popovic et al. (2006) on alfalfa. The path coefficient analysis provides information on internal relation among the investigated characteristics, as well as their effect on certain trait. The path coefficient is a standardized partial regression coefficient that measures the direct effect of one trait upon another and permits the separation of a correlation coefficient into components of direct and indirect effects (Board et al., 1997). Sodium Dodecyl Sulphate Polyacrylamide Gel Electrophoresis (SDS-PAGE is most economical simple and extensively used biochemical technique for analysis of genetic structure of germplasm (Lqbal et al., 2005). The expression of some of enzymes and proteins will be affected by growth stage of alfalfa plant (Platt, 2003).

The objectives of this study were to determine the tolerant and the sensitive cultivar (Medicajo sativa L.) under salinity stress conditions for some yield-related traits, statistical parameters and protein analysis. 


\section{Material and Methods}

In order to study the effect of salinity stress on three cultivars of alfalfa (Medicajo sativa L.) which include two local (Giza 1 and Siwa 1) and another one cultivar from abroad (Al-hasawi cultivar).This investigation was carried out in Ras-Sudr Research Station according to Desert Research Center, Egypt during 2012 and 2013 seasons. Two wells were used and irrigation water samples were collected during two years (2012 and 2013) to assess it as shown in Table 1.

Table 1. Chemical composition of irrigation water used in tow salinity levels

\begin{tabular}{|c|c|c|c|c|c|c|c|c|c|c|}
\hline \multirow{2}{*}{ Salinity level } & \multirow{2}{*}{$\mathrm{pH}$} & \multirow{2}{*}{$\mathrm{EC}\left(\mathrm{dSm}^{-1}\right)$} & \multicolumn{4}{|c|}{ Soluble cations $(\mathrm{meq} / \mathrm{L})$} & \multicolumn{4}{|c|}{ Soluble anions (meq/L) } \\
\hline & & & $\mathrm{Na}^{+}$ & $\mathrm{K}^{+}$ & $\mathrm{Ca}^{2+}$ & $\mathrm{Mg}^{2+}$ & $\mathrm{CO}_{3}{ }^{2-}$ & $\mathrm{HCO}_{3}{ }^{-}$ & $\mathrm{Cl}^{-}$ & $\mathrm{SO}_{4}{ }^{2-}$ \\
\hline Low level & 6.3 & 7.67 & 45.9 & 0.33 & 22 & 16 & - & 2 & 62.5 & 19.73 \\
\hline High level & 6.1 & 13.3 & 97.4 & 0.43 & 36 & 34 & - & 2.8 & 125 & 40.03 \\
\hline
\end{tabular}

Means of ten plants samples of each experimental unit were removed above the surface of the soil for $5 \mathrm{~cm}$. The yield of studied cultivars was estimated by measuring biomass accumulation of aerial part (shoot and leaves as fresh weight) under two salinity levels. All of studied traits measured per plant and mean of four turns in different times (two harvest for each year) represented in the second and third cutting during both 2012 and 2013 seasons.

The traits which were measured included:

Plant height $(\mathrm{cm})$, Fresh forage weight (g), Dry weight (g), (dried at $74{ }^{\circ} \mathrm{C}$ per 48 hours). Chlorophyll was measured using chlorophyll Meter SPAD-502 (MINOLTA C., LTD JAPAN 78923067). Proline content was also determined as part of the salt tolerance screening of alfalfa varieties. Free proline content ( $\mu \mathrm{mol} / \mathrm{g}$ fresh weight) in leaves was determined according to the methods of Bates et al. (1973).

Regarding, dry weight and proline content (as a proportion) data were transformed by arcsin before analysis of variance

\subsection{Stress Tolerance Index}

Six different sensitivity index suggested as stress tolerance indicators and were calculated for dry weight per plant of the tested cultivars under low salinity stress (Yl) and high salinity stress (Yh) conditions as follows:

(1) Harmonic mean (HM) (Kristin et al., 1997): HM = 2(Yl $\times \mathrm{Yh})(\mathrm{Yl}+\mathrm{Yh})$;

(2) Tolerance index (TOL) and mean productivity (MP) as performed by Rosielle and Hamblin (1981), where $\mathrm{TOL}=\mathrm{Yl}-\mathrm{Yh}$ and $\mathrm{MP}=(\mathrm{Yl}+\mathrm{Yh}) / 2$;

(3) Susceptibility stress index (SSI) (Fisher \& Maurer, 1978):

$\mathrm{SSI}=1-(\mathrm{Yh} / \mathrm{Yl}) / \mathrm{SI}$, where, $\mathrm{SI}=1-(\hat{\mathrm{Y} h} / \hat{\mathrm{Y}} \mathrm{l})=$ stress intensity and $\hat{\mathrm{Y}} \mathrm{s}$ and $\hat{\mathrm{Y}} \mathrm{n}$ are the means of all genotypes under stress and non stress conditions, respectively;

(4) Geometric mean productivity (GMP) and stress tolerance index (STI) (Fernandez, 1992; Kristin et al., 1997): $\mathrm{GMP}=(\mathrm{Yl} \times \mathrm{Yh})^{1 / 2}$ and $\mathrm{STI}=(\mathrm{Yl} \times \mathrm{Yh}) /(\hat{\mathrm{Y}} \mathrm{l})^{2}$.

\subsection{Experimental Design and Statistical Analysis}

This experiment was carried out in a split-plot design with three replication where, two salinity levels were in the main plots (as factor a) whereas, the three tested varieties were in the sub-plots (as factor b). Data of the two seasons combined after homogeneity of variance estimation using Bartlett test according to Gomez and Gomez (1984). Analysis of variance was performed on the data and significant differences among tested cultivars means under two salinity levels were calculated by Duncan's multiple range test (F0.05).

\subsection{Correlation and Path Coefficient Analysis}

The estimates of simple correlation coefficients were computed among all studied characters according to Steel and Tori (1981). Path coefficient analysis was used as determined by Dewey and Lu (1959) to partition the correlation coefficients and to determine the direct and indirect effects of studied characters on dry weight per plant. 


\subsection{SDS-Protein Electrophoresis}

Samples were taken from each tested cultivar under the two salinity levels to extract protein (SDS-PAGE). The leaves were powdered separately by liquid nitrogen; during the experiments the powders were separately kept in cold $-70{ }^{\circ} \mathrm{C}$, to time Extraction. Cultivars leaf protein were extracted by extraction buffer (Tris-HCL, $\mathrm{pH}=8.5$; NP-40, 2\%; PMSF, $1 \mathrm{mM}$ and EDTA, $1 \mathrm{mM}$ ) (Kakaei, 2009). SDS-PAGE method in resolving gel with 12.5\% acryl amid and stacking gel 5\% acrylamide was applied for extraction and resolving of these genotypes. At end of electrophoresis, protein bands were revealed by Coomassie Brilliant Blue R-250 staining and destined by methanol and acetic acid for 3 hours. Dissociating Polyacrylamide gel electrophoresis (SDS-PAGE) was adopted after Laemmli (Murphy et al., 1990).

\section{Results}

\subsection{Analysis of Variance for Studied Traits}

Statistical analysis presented in Table 2 show that, the most of means values of studied traits were significant. The presence of significant differences between salinity levels for studied traits means that varieties varied in their performance during two growing seasons. These results suggested that the comparison between varieties could be made in order to determine the best performing varieties. Assessment of means performance data of alfalfa accessions for studied traits under two salinity levels (interaction between salinity levels and tested cultivars) are presented in Figure 1. Considerable variation for salinity tolerance was observed among the three cultivars used. Generally, the increase in $\mathrm{NaCl}$ concentrations decreased all traits of all tested cultivars. All cultivars responded in same manner to salinity stress. However, the intensity of stress varied with the cultivars. All studied traits were significantly reduced as salinity concentration increased except proline content which record higher values with high salinity level (as tolerance feature). For the variance among used cultivars under two salinity levels trended the same direction of all traits except proline content trait which was non-significant. In the same manner, Al-hasawi cultivar recorded the higher values of chlorophyll content and also Siwa 1 cultivar record the higher values of plant height and fresh weight while, Giza 1 cultivar recorded the lowest values for all significant traits as sensitive cultivar while the interaction between two salinity levels and tested cultivars was significant for all traits (Table 2 and Figure 1). Regarding to dry weight trait, the interaction between two salinity levels and tested cultivars $(\mathrm{S} \times \mathrm{V})$ seems that siwa cultivar prefer to grown under low salinity level while Al-hasawi cultivar under high salinity level (Figure 1).

Table 2. Means of some yield-related traits of two salinity levels and three cultivars

\begin{tabular}{llllll}
\hline & Plant height & Fresh weight & Dry weight & Chlorophyll content & Proline content \\
\hline Low salinity & 53.583 & 12.593 & 2.013 & 30.917 & 0.417 \\
High salinity & 39.39 & 8.627 & 1.613 & 27.740 & 1.163 \\
\hline t-test (0.5) & $*$ & $*$ & $*$ & $*$ & $*$ \\
\hline Giza 1 & $41.290^{\mathrm{c}}$ & $7.42^{\mathrm{c}}$ & $1.13^{\mathrm{b}}$ & $29.065^{\mathrm{b}}$ & $0.690^{\mathrm{a}^{\mathrm{a}}}$ \\
Al-hasawi & $48.085^{\mathrm{b}}$ & $11.26^{\mathrm{b}}$ & $2.19^{\mathrm{a}}$ & $30.305^{\mathrm{a}}$ & $0.805^{\mathrm{a}}$ \\
Siwa 1 & $50.085^{\mathrm{a}}$ & $13.15^{\mathrm{a}}$ & $2.12^{\mathrm{a}}$ & $28.620^{\mathrm{c}}$ & $0.872^{\mathrm{a}}$
\end{tabular}

Note. *significant at $0.05 \%$ level (t-test), a, b and c: means with different superscripts between three cultivars in the same column are significantly different at $p<0.05$. 

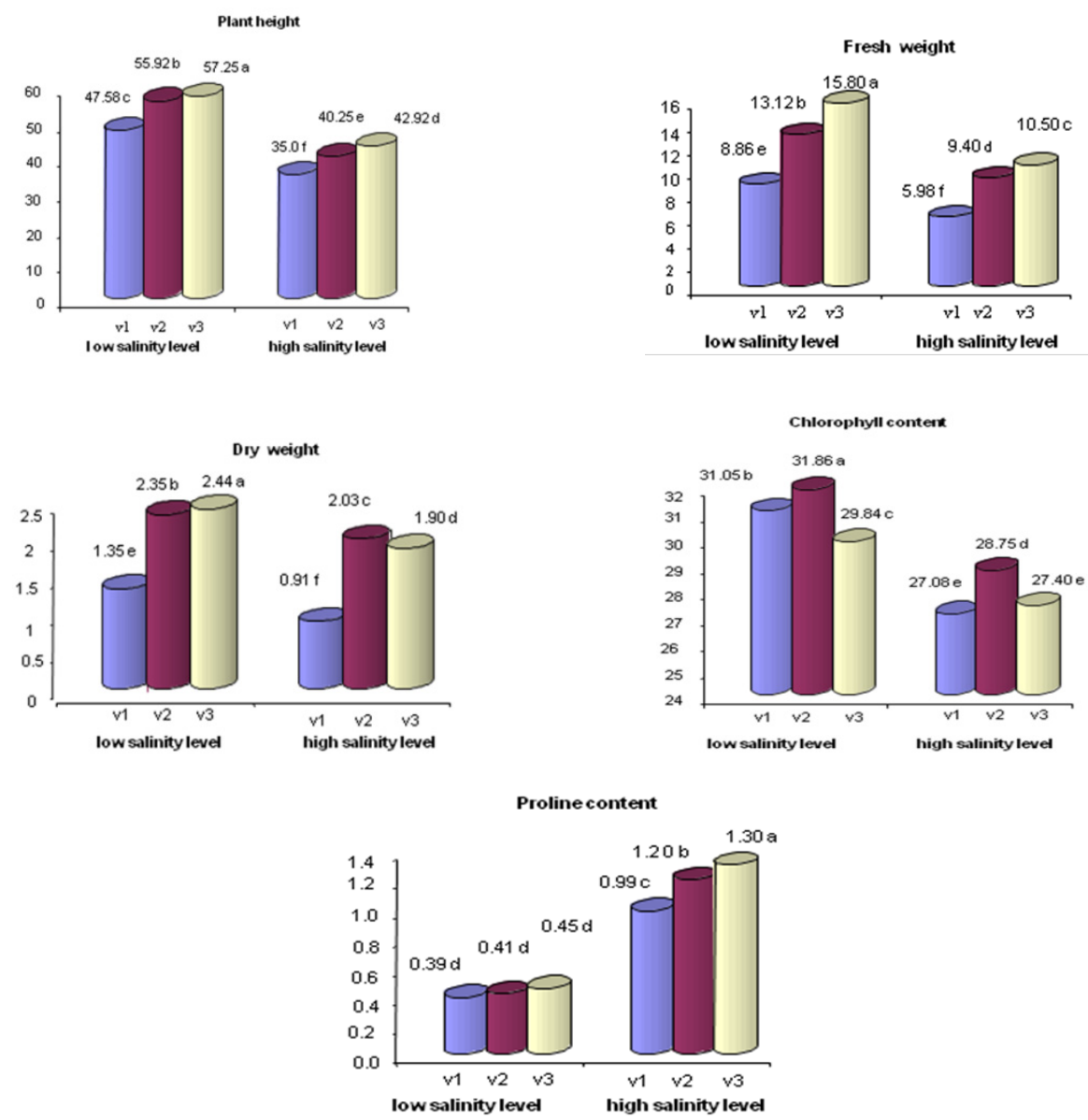

Figure 1. Effect of interaction between two salinity levels and three cultivars of alfalfa over two growth seasons

Note. V1: Giza 1 variety; V2: Al-hasawi variety; V3: Siwa 1 variety; Means, for each column above the chart, followed by similar letter are not significantly different at the $5 \%$ probability level.

\subsection{Stress Tolerance Index}

In Table 3, tolerance indicators were calculated on the basis of dry yield per plant of cultivars under two salinity levels ( $\mathrm{Y}$ low salinity and $\mathrm{Y}$ high salinity) overall two seasons. The estimates of tolerance indices attributes (Table 3) refereed to that the determination of salinity-tolerant cultivars based on a single criterion was not consistent. In this context, according to mean productivity (MP) and tolerance index (TOL) and stress susceptibility index (SSI) Al-hasawi cultivar was recorded the lower values (the most of tolerance ) while, the Giza 1 cultivar was recorded the higher values (the lowest tolerance cultivar). On the other hand, according to, geometric mean productivity (GMP), stress tolerance index (STI) and harmonic mean (HM) the desirable salinity tolerant cultivars (the higher values) were recorded of Al-hasawi followed by Siwa 1 while, Giza 1 was the least tolerant cultivar (Table 3). According to, previous results can divide the three tested cultivars under low and high salinity stress conditions for dry weight yield per plant as follow: (a) The highest cultivar to tolerance presented by Al-hasawi cultivar (b) High cultivar to tolerance presented by Siwa 1 cultivar (c) The lowest cultivar to tolerance presented by Giza 1 cultivar. 
Table 3. Salinity tolerance index of three alfalfa cultivars grown under low salinity ( $\mathrm{Y}$ low) and high salinity levels (Y high) for dry weight yield per plant

\begin{tabular}{lllllllll}
\hline \multirow{2}{*}{ Cultivars } & \multicolumn{9}{c}{ Dry weight/plant (g) } \\
\cline { 2 - 10 } & Y (low) & Y (high) & MP & TOL & GMP & STI & SSI & HM \\
\hline Gizal & 1.35 & 0.91 & 0.22 & 0.44 & 1.1083 & 0.0190 & 2.1727 & 1.0871 \\
Al-hasawi & 2.35 & 2.03 & 0.16 & 0.32 & 2.1841 & 0.0738 & 0.9077 & 2.1783 \\
Siwa1 & 2.34 & 1.9 & 0.22 & 0.44 & 2.1085 & 0.0688 & 1.2535 & 2.0971 \\
\hline Means & 2.013 & 1.613 & 0.200 & 0.400 & 1.800 & 0.054 & 1.445 & 1.788 \\
\hline
\end{tabular}

Note. Y (low): dry weight yield per plant under low salinity level; Y (high): dry weight yield per plant under high salinity level.

\subsection{Simple Correlation and Path Coefficient Analysis}

Correlation studies between characters are very important in plant breeding for indirect selection and have also been of great value in the determination of the most effective breeding procedures. The results of correlation between the traits in Table 4 show that, both plant height and dry weight traits have the highest correlation with fresh weight (91 and 89 percent respectively), while, proline trait showed the lowest correlation with dry weight.

Table 4. Correlation coefficients values between studied traits over all two salinity levels and two growth seasons

\begin{tabular}{lllll}
\hline Traits & Plant height & Fresh weight & Dry weight & ChlorophyllContent \\
\hline Fresh weight & $0.91^{* *}$ & - & & \\
Dry weight & $0.75^{* *}$ & $0.89 * *$ & - & \\
Chlorophyll Content & $0.79 * *$ & $0.52^{*}$ & $0.46 *$ & - \\
Proline Content & $-0.77^{* *}$ & $-0.48^{*}$ & $-0.20 \mathrm{~ns}$ & $-0.86^{* *}$ \\
\hline
\end{tabular}

Note. ns: not significant; * and **: significant at the 0.05 and 0.01 level of probability, respectively.

We can process the data by the path-coefficient analysis which enabled the partitioning of the direct and indirect effects of used traits on dry weight per plant as selection criteria in alfalfa plant breeding. Path coefficient analysis was conducted by considering dry weight-related traits as predictor variables as the response variable. This method allowed separation of the correlation coefficients with components of direct and indirect effects (Table 5).

Moderately high positive direct effect of chlorophyll content was important contributor (0.693) and it also contributes indirectly and positively on dry weight per plant through plant height and fresh weight $(0.454,0.287$ respectively). While, the indirect negative effect was contributed through proline content (-0.976). Positive direct effect of chlorophyll content suggests that direct selection for this trait for dry weight per plant would be effective. According to path analysis, proline content had highest positive direct effect on dry weight per plant (1.135) but it was contributed through the other traits by negative indirect effects. However, the deleterious negative indirect effect was neutralized by its positive direct effect of proline content on dry weight per plant under salinity stress (Table 5).

Table 5. Partition of correlation coefficients into direct and indirect effect for mean dry weight per plant under salinity stress conditions

\begin{tabular}{|c|c|c|c|c|c|c|}
\hline \multirow[b]{2}{*}{ Trait } & \multirow{2}{*}{$\begin{array}{l}\text { Total Correlation } \\
\text { with dry weight }\end{array}$} & \multicolumn{4}{|c|}{ Indirect effect via } & \multirow[b]{2}{*}{ Direct effect } \\
\hline & & $\begin{array}{l}\text { Plant } \\
\text { height }\end{array}$ & $\begin{array}{l}\text { Fresh } \\
\text { weight }\end{array}$ & $\begin{array}{l}\text { Chlorophyll } \\
\text { Content }\end{array}$ & $\begin{array}{l}\text { Proline } \\
\text { content }\end{array}$ & \\
\hline Plant height & 0.75 & - & 0.502 & 0.547 & -0.874 & 0.574 \\
\hline Fresh weight & 0.89 & 0.523 & - & 0.360 & -0.545 & 0.552 \\
\hline Chlorophyll Content & 0.46 & 0.454 & 0.287 & - & -0.976 & 0.693 \\
\hline Proline content & -0.20 & -0.442 & -0.265 & -0.596 & - & 1.135 \\
\hline
\end{tabular}




\subsection{Biochemical Genetic Studies for Salt Tolerance}

Data of SDS-PAGE for protein in leaves was carried out of three alfalfa varieties tested under two salinity levels and illustrated in Figure 2 and Table 6. Protein bands with different molecular weights were detected under Ras-Sudr region conditions at Sinai and ranging from about 7 bands to 14 bands. In the same manner, the bands with different molecular weights were detected under two salinity level and ranging from $10.4 \mathrm{kDa}$ to $120 \mathrm{kDa}$. Based on previous results (salinity tolerance index) it seems that Al-hasawi and Siwa 1 cultivars have greater tolerance than Giza 1 cultivar to severe salinity stress. Also, the same trend of both tolerant cultivars recorded the same positive molecular weights $(29.5,33.9,37$ and $60.2 \mathrm{kDa})$ compare with sensitive cultivar under two salinity levels.

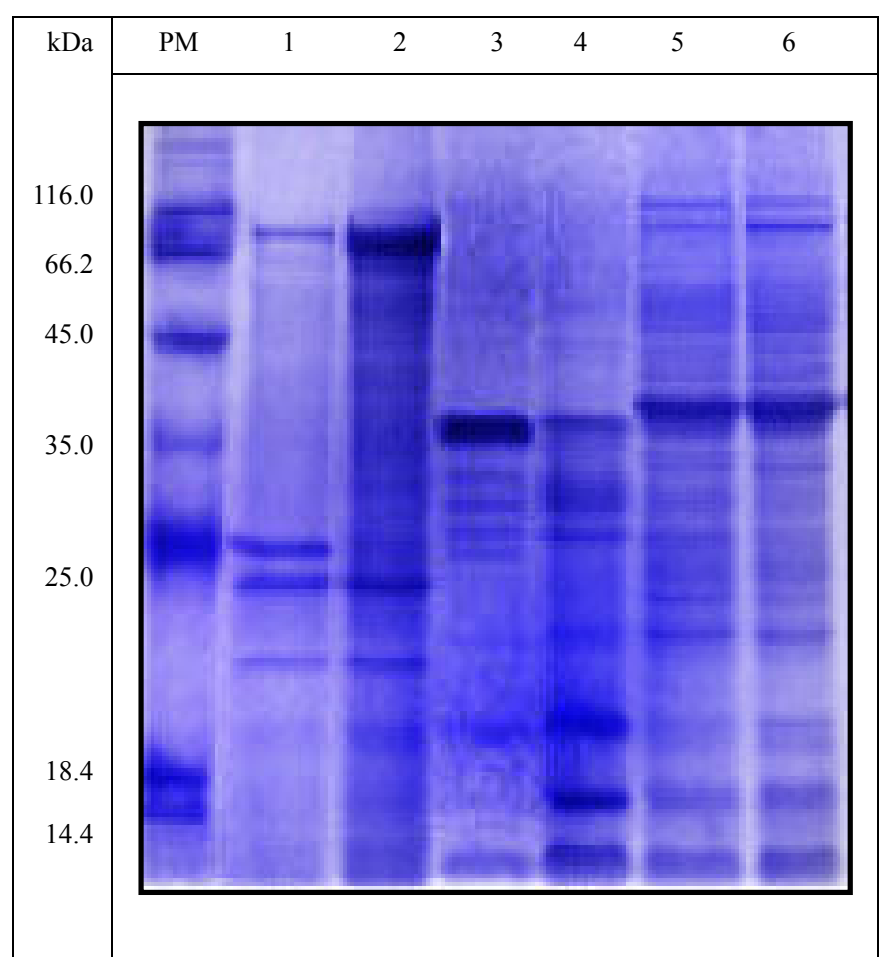

Figure 2. SDS-protein banding pattern in leaves of three alfalfa cultivars under two salinity levels

Note. PM: protein marker; 1, 2: Giza 1 under low and high salinity levels; 3, 4: Al-hasawi under low and high salinity levels; 5, 6: Siwa 1 under low and high salinity levels respectively.

There were four monomorphic bands (common bands) with molecular weights ranging from $10.4 \mathrm{kDa}$ to $63 \mathrm{kDa}$ and the remainders were polymorphic bands with a percentage of $75 \%$ (Table 7 ). Bolymorphic bands with molecular weights $(29.5,33.9,37$ and $60.2 \mathrm{kDa})$ negatively differentiate for sensitive variety (Giza 1$)$. Such specific bands could be used to distinguish the salt tolerant alfalfa varieties others (Al-hasawi and Siwa 1). 
Table 6. The presence (+) and absence (-) of leaves protein profile of three alfalfa cultivars under two salinity levels

\begin{tabular}{|c|c|c|c|c|c|c|}
\hline Molecular weight $(\mathrm{kDa})$ & $\begin{array}{l}\text { Giza } 1 \\
\text { (low salinity) }\end{array}$ & $\begin{array}{l}\text { Giza } 1 \\
\text { (high salinity) }\end{array}$ & $\begin{array}{l}\text { Al-hasawi } \\
\text { (low salinity) }\end{array}$ & $\begin{array}{l}\text { Al-hasawi } \\
\text { (high salinity) }\end{array}$ & $\begin{array}{l}\text { Siwa } 1 \\
\text { (low salinity) }\end{array}$ & $\begin{array}{l}\text { Siwa } 1 \\
\text { (high salinity) }\end{array}$ \\
\hline 120 & - & - & - & - & + & + \\
\hline 99.8 & + & + & - & - & + & + \\
\hline 63 & + & + & + & + & + & + \\
\hline 60.2 & - & - & + & + & + & + \\
\hline 44 & - & + & + & + & + & + \\
\hline 43 & - & - & - & - & + & + \\
\hline 40.5 & + & + & - & - & + & + \\
\hline 37 & - & - & + & + & + & + \\
\hline 33.9 & - & - & + & + & + & + \\
\hline 29.5 & - & - & + & + & + & + \\
\hline 25 & + & + & + & + & + & + \\
\hline 22 & - & - & + & - & - & - \\
\hline 21.4 & + & + & - & - & - & - \\
\hline 19.1 & + & + & + & + & + & + \\
\hline 16.4 & - & - & - & + & + & + \\
\hline 10.4 & + & + & + & + & + & + \\
\hline Total & 7 & 8 & 10 & 10 & 14 & 14 \\
\hline
\end{tabular}

Table 7. Types, numbers and percentage of monomorphic and polymorphic

\begin{tabular}{lllll}
\hline Monomorphic bands & Polymorphic bands & Total & Monomorphic (\%) & Polymorphic (\%) \\
\hline 4 & 12 & 16 & 25 & 75 \\
\hline
\end{tabular}

\section{Discussion}

Plant growth is one of the most important agricultural parameters of salt stress tolerance as indicated by different studies (Voigt et al., 2009). Our data showed that salt treatment negatively affected plant growth by the reduction of the most traits with significant differences between the used alfalfa varieties (Table 2 and Figure 1).

The reduction of alfalfa growth following $\mathrm{NaCl}$ addition has been widely argued in the literature (Torabi \& Halim, 2010; Farissi et al., 2011). Studies performed on other species, under saline conditions, show that the growth inhibition is due to a nutrient uptake alteration (Sibole et al., 2003; Mohammadi et al., 2008) or to a toxic $\mathrm{Na}$ and Cl intra-cellular concentration occurring in the stressed plants (Sannazzaro et al., 2007). On the other hand, with increasing $\mathrm{NaCl}$ concentration (Figure 1), the proline content recorded in shoots of all varieties significantly increased as many researches have already reported (Petrusa \& Winicov, 1997; Chelli-Chaabouni et al., 2010; Torabi \& Halim, 2010). This increase led us to think that proline was involved in salt tolerance and osmotic adjustment, protecting the plants against the induced salt damages (Szabados \& Savouré, 2010).

Genotypes with low drought susceptibility index (DSI) values (less than 1) can be considered drought resistant (Bruckner \& Frohberg, 1987), because they exhibited smaller yield reductions under water stress compared with well-watered conditions than the mean of all genotypes. The present study of stress tolerance index under salinity stress conditions in Table 3 are going the same trend of previous studies. In the same manner, Petcu et al. (2014) reported that selection for twenty four genotypes based on drought susceptibility index (DSI) may provide a more desirable criterion for improving drought resistance in alfalfa (Medicago sativa L.). Also, Golabadi et al. (2006) found that STI, MP, and GMP are superior indices for selecting high yield durum wheat genotypes both under moisture stress and non-stress field environments. Pourdad (2008) reported that STI was the best index to identify superior cultivated safflower genotypes in conditions both with and without drought 
stress. In the same manner, Talebi et al. (2009) reported that cultivars producing high yield in both drought and well watered conditions can be identified by STI, GMP and MP values. Pireivatlou et al. (2010) was also noted that STI can be a reliable index for selecting high yielding genotypes. There are many reports concerning the correlation between salt protein levels and the level of salinity tolerance using the physiological parameters such as photochemical efficiency of photosynthesis and net photosynthesis rate (Theerakulpisut et al., 2004). Moreover, $\mathrm{Na}^{+} / \mathrm{K}^{+}$ratio and chlorophyll content can be used as an indication of the stress tolerance capacity in rice and used for screening salt-tolerant lines of rice (Kong-Ngern et al., 2001). In the present work, path coefficient analysis showed that both chlorophyll and proline content participated to the osmotic adjustment in plants exposed to the salt stress through dry weight (Table 5). In general, different studies reported that chlorophyll content is one of the most important traits in the water deficit states (Poormohammad Kiani et al., 2008).

Results showed that the protein electrophoresis under salinity stress conditions as important indicator for evaluate alfalfa varieties (Figure 2 and Table 6). Many of the previous studies have confirmed that, plants species may change their response to salt stress by alter their gene expression and protein accumulation to reduce the effects of salt stress. Adaptation of plants to saline conditions may be due to some salt-related changes in the pattern of gene(s) expression. So, salinity-induced changes in protein have been reported in several plant species (Winicov et al., 1989; Jain et al., 1993). Indeed, protein electrophoresis is one of the methods for determinate genetic diversity in plants and banding pattern and grouping genotypes in both normal and drought conditions were different (Kakaei et al., 2010).

\section{Conclusion}

The data presented here revealed that, the salinity tolerance indicators (stress susceptibility index) confirm that, the highest cultivar to tolerance presented by Al-hasawi cultivar and high cultivar to tolerance presented by Siwa 1 cultivar while the lowest cultivar to tolerance presented by Giza 1 cultivar. Furthermore, path coefficient analysis showed that, proline and chlorophyll content traits are very important and should be given high weightage in any selection process aimed at improving dry weight per plant in alfalfa plant under salinity stress. Moreover, this investigation reported that some molecular weights of some salt responsive proteins are necessary to further investigate the structural and functional roles of this salt stress. Genetic differences among studied cultivars have probably originated through geographical isolation or by genetic drift and selection in different environments. So, the degree of geographical separation and the degree of genotypes relationship, as far as it is known, can be used as indicators of genetic diversity depending on some parameters which play important role in any breeding program.

\section{References}

Bates, L. S., Waldren, R. P., \& Teare, I. D. (1973). Rapid determination of free proline for water stress studies. Plant Soil, 39, 205-207. http://dx.doi.org/10.1007/BF00018060

Board, J. E., Kang, M. S., \& Hartville, B. G. (1997). Path analyses identify indirect selection criteria for yield of

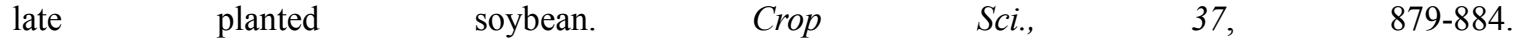
http://dx.doi.org/10.2135/cropsci1997.0011183X003700030030x

Brown, P. W., \& Tanner, C. B. (1983). Alfalfa stem and leaf growth during water stress. Agron. J., 75, 799-805. http://dx.doi.org/10.2134/agronj1983.00021962007500050017x

Bruckner, P. L., \& Frohberg, R. C. (1987). Stress tolerance adaptation in spring wheat. Crop Sci., 27, 31 -36. http://dx.doi.org/10.2135/cropsci1987.0011183X002700010008x

Carter, P. R., \& Sheafer, C. C. (1983a). Alfalfa response to soil water deficits. I. Growth, forage quality, yield, water use, and water use efficiency. Crop Sci., 23, 669-675. http://dx.doi.org/10.2135/cropsci1983.0011183X002300040016x

Chelli-Chaabouni, A., Mosbah, A. B., Maalej, M., Gargouri, K., Gargouri-Bouzid, R., \& Drira, N. (2010). In vitro salinity tolerance of two pistachio rootstocks: Pistacia vera L. and P. atlantica Desf. Environ. Exp. Bot., 69, 302-312. http://dx.doi.org/10.1016/j.envexpbot.2010.05.010

Clarke, J. M., DePauw, R. M., \& Townley-Smith, T. F. (1992). Evaluation of methods for quantification of $\begin{array}{llllll}\text { drought } \quad \text { in } & \text { Crop }\end{array}$ http://dx.doi.org/10.2135/cropsci1992.0011183X003200030029x

Dewey, D. R., \& Lu, K. H. (1959). A correlation and path coefficient of components of crested wheat grain production. Agron. J., 51(9), 515-518. http://dx.doi.org/10.2134/agronj1959.00021962005100090002x 
Farissi, M., Bouizgaren, A., Faghire, M., Bargaz, A., \& Ghoulam, C. (2011). Agro-physiological responses of Moroccan alfalfa (Medicago sativa L.) populations to salt stress during germination and early seedling stages. Seed Sci. Technol., 39, 389-401. http://dx.doi.org/10.15258/sst.2011.39.2.11

Fernandez, G. C. J. (1992). Effective selection criteria for assessing plant stress tolerance. Proceedings of the international symposium on adaptation of vegetable and other food crops in temperature and water stress (pp. 257-270). Taiwan.

Fischer, R. A., \& Maurer, R. (1978). Drought resistance in spring wheat (Triticum aestivum L.) cultivars. I. grain yield response. Aust. J. Agric. Res., 29, 897-912. http://dx.doi.org/10.1071/AR9780897

Golabadi, M., Arzani, A., \& Maibody, S. A. M. (2006). Assessment of drought tolerance in segregating populations in durum wheat. Afr. J. Agric. Res., 5, 162-171.

Gomez, K. A., \& Gomez, A. A. (1984). Statistical procedures for agriculture research (2nd ed., pp. 95-109). John Willy\& Sons Inc., New York, USA.

Jain, S., Nainawatee, H. S., Jain, R. K., \& Chowdhury, J. B. (1993). Salt-tolerance in Brassica juncea L. П. Salt-stress induced changes in polypeptide pattern of in vitro selected NaCl-tolerant plants. Euphytica., 65, 107-112. http://dx.doi.org/10.1007/BF00022572

Julier, B., Huyghe, C., \& Ecalle, C. (2000). Within- and among-cultivar genetic variation in alfalfa: forage quality, morphology, and yield. Crop Sci., 40, 365-369. http://dx.doi.org/10.2135/cropsci2000.402365x

Kakaei, M. (2009). Effects of genotype and drought stress on physiological, morphological, phonological and biochemical traits of winter rape (Brassica napus L.) (M.Sc. Thesis). Islamic Azad University, Branch of Kermansha, Iran.

Kakaei, M., Zebarjadi, A., \& Mostafaie, A. (2010). Study of protein pattern in Brassica napus genotypes under non-stress and drought stress conditions. Agricultural Biotechnology, 9(2), 49-57.

Katerji, N., van Hoorn, J. W., Hamdy, A., \& Mastrorilli, M. (2003). Salinity effect on crop development and yield analysis of salt tolerance according to several classification methods. Agric. Water Manage, 62, 37-66. http://dx.doi.org/10.1016/S0378-3774(03)00005-2

Kong-ngern, K., Theerakulpisut, P., Bunnag, S., Kosittrakun, M., \& Daduang, S. (2001). Salt tolerance in rice: glasshouse screening, field experiment and salt-induced polypeptides. $K K U \operatorname{Res} J(G S), 1,26-32$.

Kristin, A. S., Senra, R. R., Perez, F. I., Enriquez, B. C., Gallegos, J. A. A., Vallego, P. R., ... Kelley, J. D. (1997). Improving common bean performance under drought stress. Crop Sci., 37, 43-50. http://dx.doi.org/10.2135/cropsci1997.0011183X003700010007x

Lqbal, S. H., Ghafoor, A., \& Ayub, N. (2005). Relationship between SDS-PAGE markers and Ascochyta blight in chickpea. Pak J. Bot., 37, 87-96.

Mass, E., \& Hoffman, G. (1977). Crop salt tolerance - Current assessment. J. Irrig. Drain., 103, 115-134.

Mitra, J. (2001). Genetics and genetic improvement of drought resistance in crop plants. Current Sci., 80, 758-762.

Mohammadi, H., Poustini, K., \& Ahmadi, A. (2008). Root nitrogen remobilization and ion status of two alfalfa (Medicago sativa L.) cultivars in response to salinity stress. J. Agron. Crop Sci., 194, 126-134. http://dx.doi.org/10.1111/j.1439-037X.2008.00294.X

Munns, R., Husain, S., Rivelli, A. R., James, R. A., Condon, A. G., \& Lindsay, M. P. (2002). Avenues for increasing salt tolerance of crops, and the role of physiologically based selection traits. Plant Soil, 247, 93-105. http://dx.doi.org/10.1023/A:1021119414799

Murphy, R. W., Sites, J. W., Buth, D. G., \& Haufler, C. H. (1990). Protein I: Isozyme electrophoresis. In D. H. Hillis \& C. Moritz (Eds.), Molecular systematic (pp. 45-126). Sinauer Assoc., Sunderland, MA.

Petcu, E., Schitea, M. D., \& Lenuta, D. (2014). The effect of water stress on stomatal resistance and chlorophyll fluorescence and their association with alfalfa yield. Romanian Agricultural Research, 31, 113-119.

Petrusa, L., \& Winicov, I. (1997). Proline status in salt-tolerante and salt sensitive alfalfa cell lines and plants in response to NaCl. Plant Physiol. Biochem., 35, 303-310.

Pireivatlou, A. S., Masjedlou, B. D., \& Aliyev, R. T. (2010). Evaluation of yield potential and stress adaptive trait in wheat genotypes under post an thesis drought stress conditions. Afr. J. Agric. Res., 5, 2829-2836. 
Platt, T. (2003). Alfalfa's Potential in Dry land Crop Production. WSU Area Extension Educator, Davenport.

Poormohammad, K. S., Maury, P., Sarrafi, A., \& Grieu, P. (2008). QTL analysis of chlorophyll fluorescence parameters in sunflower (Helianthus annuus L.) under well-watered and water-stressed conditions. Plant Sci, 175, 565-573. http://dx.doi.org/10.1016/j.plantsci.2008.06.002

Popovic, S., Cupic, T., Grljusic, S., \& Tucak, M. (2006). Use of variability and path analysis in determining yield and quality of alfalfa. Proceedings of XXVI Meeting of the EUCARPIA Fodder Crops and amenity Grasses Section (pp. 95-99). Perugia, Italy.

Pourdad, S. S. (2008). Study of drought resistance indices in spring safflower. Acta Agron. Hung., 56, 203-212. http://dx.doi.org/10.1556/AAgr.56.2008.2.9

Rosielle, A. A., \& Hamblin, J. (1981). Theoretical aspects of selection for yield in stress and non-stress environment. Crop Sci., 21, 943-946. http://dx.doi.org/10.2135/cropsci1981.0011183X002100060033x

Sannazzaro, A. I., Echeverría, M., Albertó, E. O., Ruiz, O. A., \& Menéndez, A. B. (2007). Modulation of polyamine balance in Lotus glaber by salinity and arbuscular mycorrhiza, Plant Physiol. Biochem., 45, 39-46. http://dx.doi.org/10.1016/j.plaphy.2006.12.008

Sibole, J. V., Cabot, C., Poschenrieder, C., \& Barcelo J. (2003). Ion allocation in two different salt-tolerant Mediterranean Medicago species. J. Plant Physiol., 160, 1361-1365. http://dx.doi.org/10.1078/0176-1617-00811

Steel, R. C. D., \& Torrie, J. H. (1981). Principles and Procedures of Statistics. McGraw- Hill, New York, USA.

Szabados, L., \& Savouré, A. (2010). Proline: a multifunctional amino acid. Trends Plant Sci., 15, 89-97. http://dx.doi.org/10.1016/j.tplants.2009.11.009

Talebi, R., Fayaz, F., \& Naji, A. M. (2009). Effective selection criteria for assessing drought stress tolerance in durum wheat (Triticum durum Desf.). General and Appl. Plant Physiol., 35, 64-74.

Theerakulpisut, P., Bunnag, S., \& Kong-Ngern, K. (2005). Genetic diversity, salinity tolerance and physiological responses to $\mathrm{NaCl}$ of six rice (Oryza sativa L.) cultivars. Asian J. Plant Sci., 4(6), 562-573. http://dx.doi.org/10.3923/ajps.2005.562.573

Torabi, M., \& Halim, M. R. A. (2010). Variation of root and shoot growth and free proline accumulation in Iranian alfalfa ecotypes under salt stress, J. Food Agric. Environ., 8, 323-327.

Valliy, B., \& Nguyen, H. T. (2006). Understanding regulatory networks and engineering for enhanced drought tolerance in plants. Current Opinion in Plant Biology, 9, 1-7.

Voigt, E. L., Almeida, T. D., Chagas, R. M., Ponte, L. F., Viégas, R. A., \& Silveira, J. A. (2009). Source - sink regulation of cotyledonary reserve mobilization during cashew (Anacardium occidentale) seedling

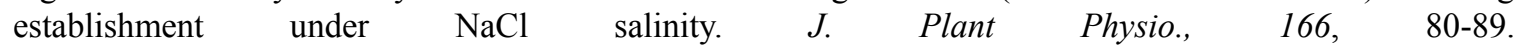
http://dx.doi.org/10.1016/j.jplph.2008.02.008

Wang, X., Yang, X., Chen, L., Feng, G., Zhang, J., \& Jin, L. (2011). Genetic diversity among alfalfa (Medicago sativa L.) cultivars in Northwest China. Acta Agr. Scand. B, 61, 60-67. http://dx.doi.org/10.1080/09064710903496519

Winicov, L., Waterborg, J. H., Harrington, R. E., Coy, M. C., \& Silveira, T. Y. (1989). Messenger RNA induction in cellular salt tolerance of alfalfa (Medicago Sativa L.). Plant cell Rep., 8, 6-11. http://dx.doi.org/10.1007/BF00735767

\section{Copyrights}

Copyright for this article is retained by the author(s), with first publication rights granted to the journal.

This is an open-access article distributed under the terms and conditions of the Creative Commons Attribution license (http://creativecommons.org/licenses/by/3.0/). 